\title{
Pengaruh Kompensasi Finansial Dan Nonfinansial Terhadap Kepuasan Kerja Dan Kinerja Karyawan Pada PT. Cindara Pratama Lines Balikpapan
}

\author{
Arkas Viddy ${ }^{1 *}$, Gunadi ${ }^{2}$, dan Syarifah Fahma Nida Aulia ${ }^{3}$ \\ ${ }^{123}$ Program Studi Administrasi Bisnis, Politeknik Negeri Samarinda, Samarinda 75131 \\ *Correspondent Author \\ E-mail: viddyarkas@polnes.ac.id
}

Diterima: 02 Maret $2019 \quad$ Direvisi: 28 April $2019 \quad$ Disetujui: 29 Mei 2020

\begin{abstract}
Abstrak
Pengaruh Kompensasi Finansial dan Nonfinansial terhadap Kepuasan Kerja dan Kinerja Karyawan. Penelitian ini bertujuan untuk mengetahui pengaruh kompensasi finansial dan nonfinansial terhadap kepuasan kerja dan kinerja karyawan pada PT Cindara Pratama Lines Balikpapan. Dengan Subjek penelitian ini adalah semua karyawan bagian PT Cindara Pratama Lines Balikpapan dengan jumlah 50 orang. Pengumpulan data menggunakan kuesioner yang telah diuji validitas dan reliabilitasnya sedangkan analisis data dilakukan dengan menggunakan analisis regresi linear berganda. dengan alat analisis Path Analisis menggunakan Smart PLS, dan SPSS. Hasil penelitian menunjukkan bahwa: 1) Variabel Kompensasi Finansial (X1) berpengaruh signifikan terhadap Kepuasan Kerja Karyawan (Y1) pada PT Cindara Pratama Lines Balikpapan, 2) Variabel Kompensasi Finansial (X1) tidak berpengaruh signifikan terhadap Kinerja Karyawan (Y2) pada PT Cindara Pratama Lines Balikpapan, 3) Variabel Kompensasi Nonfinansial (X2) tidak berpengaruh signifikan terhadap Kepuasan Karyawan (Y2) pada PT Cindara Pratama Lines Balikpapan. 4) Variabel Kompensasi Nonfinansial (X2) tidak berpengaruh signifikan terhadap Kinerja Karyawan (Y2) pada PT Cindara Pratama Lines Balikpapan, 5) Variabel Kepuasan Kerja (Y1) berpengaruh signifikan terhadap Kinerja Karyawan (Y2) pada PT Cindara Pratama Lines Balikpapan.
\end{abstract}

Kata kunci: Kompensasi Finansial, Kompensasi Nonfinansial, Kepuasan Kerja dan Kinerja Karyawan.

\begin{abstract}
The Influences of Financial Compensation and Non-Financial Compensation on Working Satisfaction and Working Performance in PT. Cindara Pratama Lines Balikpapan. The purpose of this research is to identify the influences of Financial Compensation and Non-Financial Compensation on Working Satisfaction and Working Performance in PT. Cindara Pratama Lines Balikpapan. The respondents of this research are 50 employees of PT. Cindara Pratama Lines Balikpapan. All of the questioners collected are examined to ensure all the items are valid and reliable. Path Analysis instrument been used for analyzing the research. Smart PLS and SPSS Software would be used for examining the path coefficient. The result of this research are : 1. Financial Compensation (X1) has a significant effect on Working Satisfaction (Y1), 2. Financial Compensation (X2) has a significant effect on Working Performance (Y2), 3. Non-Financial Compensation (X2) has a significant on Working Satisfaction (Y1), 4. Non-Financial Compensation (X2) has a significant effect on Working Performance (Y2), and 5. Working Satisfaction (Y1) has a significant effect on Working Performance (Y2) in PT. Cindara Pratama Lines Balikpapan
\end{abstract}

Keywords: Financial Compensation, Non-Financial Performance, Working Satisfaction, Working Performance 


\section{PENDAHULUAN}

PT Cindara Pratama Lines Balikpapan merupakan perusahaan perseroan yang bergerak dibidang pengangkutan dengan moda air dan moda darat, perindustrian dan pemasaran Bahan Bakar Minyak (BBM) milik PT. Pertamina (Persero). Fenomena yang terjadi pada 1 tahun terakhir adalah adanya ketidak sesuaian antara ketentuan upah dan waktu kerja lembur yang diatur dalam Undang-Undang No.13 Tahun 2003 tentang ketenagakerjaan Pasal 78 ayat (2), (4) dan Pasal 85 dan lebih lengkapnya diatur dalam Keputusan Menteri Tenaga Kerja dan Transmigrasi No.102/MEN/VI/2004 mengenai waktu dan upah kerja lembur. Selain itu, karyawan PT Cindara Pratama Lines Balikpapan memiliki gaji yang tidak sesuai dengan resiko yang dikerjakannya semisal karyawan K3 yang hanya diberi gaji sebesar Rp.3.500.000,- yang tergolong sangat kecil untuk pekerjaan yang beresiko tinggi dan untuk upah lembur hanya diberi Rp.13.000,-/jam yang seharusnya upah lembur ditetapkan dari gaji sebulan dibagi perhari lalu dibagi lagi menjadi upah perjamnya, misal Rp.3.500.000/30 = Rp. 117.000,- / 8 jam = Rp.14.500,- , maka Rp.14.500,itulah yang seharusnya dijadikan upah lembur dan upah lembur tersebut dikali lipatkan sesuai dengan waktu lembur. Namun pada kenyataanya upah lembur tersebut tidak dikali lipatkan sesuai dengan peraturan yang telah ditetapkan. Maka dari itu perusahaan perlu meningkatkan kompensasi secara optimal agar kinerja dan kepuasan karyawan meningkat.

Manajemen berasal dari kata "to manage" yang artinya mengatur. Pengaturan dilakukan melalui proses dan diatur berdasarkan urutan dan fungsi-fungsi manajemen itu. Manajemen adalah ilmu dan seni mengatur proses pemanfaatan sumber daya manusia dan sumber-sumber daya lainnya secara efektif dan efisien untuk mencapai suatu tujuan tertentu. (Hasibuan D. H., 2011, hal. 9). Manajemen ini terdiri dari enam unsur (6 M) yaitu: Men, Money, Methode, Materials, Machines dan Market. Unsur men (manusia) ini berkembang menjadi suatu bidang ilmu manajemen yang disebut manajemen sumber daya manusia atau disingkat MSDM yang merupakan terjemahan dari man power management. Menurut Drs. H. Malayu S.P Hasibuan dalam buku Manajemen Sumber Daya Manusia mengemukakan bahwa, "Kompenasasi adalah semua pendapatan yang berbentuk uang, barang langsung atau tidak langsung diterima karyawan sebagai imbalan atas jasa yang diberikan kepada perusahaan." (Hasibuan D. H., 2011, hal. 118). Menurut Kreitner dan Kinicky kepuasan kerja adalah "Suatu efektifitas atau respons emosional terhadap berbagai aspek pekerjaan". Kepuasan kerja dipandang sebagai sesuatu yang relatif, yang berbeda dari pemikiran objektif dan keinginan perilaku. (Kreitner \& Kinicky, 2001, hal. 271). Menurut (Hariandja, Manajemen Sumber Daya Manusia, 2002, hal. 291) indikator-indikator yang mempengaruhi kepuasan kerja yang berkaitan dengan beberapa aspek yaitu 1, gaji. 2, pekerjaan. 3, rekan kerja. 4, atasan. 5, promosi. Kinerja Karyawan. Menurut (Mangkunegara A. P., 2000, hal. 67) bahwa, "Kinerja (prestasi kerja) adalah hasil kerja secara kualitas dan kuantitas yang dicapai oleh seorang pegawai dalam melaksanakan tugasnya dengan tanggung jawab yang diberikan kepadanya".

\section{Hipotesis Penelitian}

Hipotesis adalah suatu jawaban yang bersifat sementara mengenai suatu permasalahan yang dibuat untuk dibuktikan kebenarannya secara empiris. Sesuai dengan permasalahannya, maka dirumuskan hipotesis penelitian ini sebagai berikut :

1) $\mathrm{H}_{0}: \propto_{1}=0 \rightarrow$ Tidak Terdapat pengaruh signifikan Kompensasi Finansial Terhadap Kepuasan Kerja

$\mathrm{H}_{\mathrm{a}}: \propto_{1} \neq 0 \rightarrow$ Terdapat pengaruh signifikan Kompensasi Finansial Terhadap Kinerja Karyawan

2) $\mathrm{H}_{0}: \propto_{1}=0 \rightarrow$ Tidak Terdapat pengaruh signifikan Kompensasi Non Finansial Terhadap Kepuasan Kerja

$\mathrm{H}_{\mathrm{a}}: \propto_{1} \neq 0 \rightarrow$ Terdapat pengaruh signifikan Kompensasi Non Finansial Terhadap Kepuasan Kerja 
3) $\mathrm{H}_{0}: \propto_{1}=0 \rightarrow$ Tidak Terdapat pengaruh signifikan Kompensasi Finansial Terhadap Kinerja Karyawan

$\mathrm{H}_{\mathrm{a}}: \propto_{1} \neq 0 \rightarrow$ Terdapat pengaruh signifikan Kompensasi Finansial Terhadap Kinerja Karyawan

4) $\mathrm{H}_{0}: \propto_{1}=0 \rightarrow$ Tidak Terdapat pengaruh signifikan Kompensasi Non Finansial Terhadap Kinerja Karyawan

$\mathrm{H}_{\mathrm{a}}: \propto_{1} \neq 0 \rightarrow$ Terdapat pengaruh signifikan Kompensasi Finansial Terhadap Kinerja Karyawan

5) $\mathrm{H}_{0}: \propto_{1}=0 \rightarrow$ Tidak Terdapat pengaruh signifikan Kepuasan Kerja Terhadap Kinerja Karyawan

$\mathrm{H}_{\mathrm{a}}: \propto_{1} \neq 0 \rightarrow$ Terdapat pengaruh signifikan Kepuasan Kerja Terhadap Kinerja Karyawan

\section{METODOLOGI}

Penelitian ini akan dilakukan di PT. Cindara Pratama Lines, Jl. Letjen Suprapto No.16 RT. 28, Kota Balikpapan, Waktu penelitian dilaksanakan di bulan Juni 2019 sampai selesai. Populasi dalam penelitian ini adalah karyawan yang bekerja di PT. Cindara Pratama Lines yang berjumlah 80. Sampel yang digunakan yaitu karyawan yang telah bekerja di PT. Cindara Pratama Lines selama 1 tahun atau lebih. Sampel yang digunakan sebanyak 50 orang. Menurut (Arikunto, Prosedur Penelitian Suatu Pendekatan Praktik, 2006) menyatakan : "Sampel adalah sebagian atau wakil populasi yang diteliti". Untuk sekedar ecer-ecer, apabila subjeknya kurang dari 100 lebih baik diambil semua sehingga penelitinya merupakan penelitian populasi. Tetapi, jika jumlah subjeknya besar dapat di ambil antara $1-15 \%$ atau $20-25 \%$ atau lebih. Dari pendapat tersebut peneliti menggunakan keseluruhan populasi sebagai sampel penelitian ini.

\section{Teknik Pengambilan Sampel}

Teknik pengambilan sampel menggunakan Accidental Sampling. Menurut (Sugiyono, 2009:85), Accidental Sampling adalah teknik penentuan sampel berdasarkan kebetulan, yaitu konsumen yang secara kebetulan/insidental bertemu dengan peneliti dapat digunakan sebagai sampel, bila dipandang orang yang kebetulan yang ditemui itu cocok sebagai sumber data.

\section{Teknik Pengumpulan Data}

Metode pengumpulan data yang digunakan untuk memperoleh data dalam penelitian ini adalah field research atau studi lapangan, yaitu penelitian yang dilakukan secara langsung dengan membagikan kuisoner kepada reponden yang dianggap memenuhi syarat. Sumber data yang digunakan adalah data primer dikumpulkan melalui kuisoner yang dibagikan pada responden. Kuisoner ini digunakan untuk mengukur kompensasi finansial, kompensasi nonfinansial, kepuasan kerja dan kinerja karyawan. Data primer biasanya diperoleh dari survei lapangan yang menggunakan semua metode pengumpulan data ordinal (Sugiyono, 2002)

Pengumpulan data tersebut dengan cara membagikan daftar pertanyaan ataupun pernyataan kepada responden yaitu karyawan PT. Cindara Pratama Lines. Daftar pertanyaan ataupun pernyataan tertulis yang dibagikan kepada responden berisi masalah yang berkaitan dengan objek yang diteliti sesuai dengan indikator-indikator variabel pada kisi-kisi instrumen penelitian. Daftar pertanyaan ataupun pernyataan tersebut disusun dalam sebuah kuesioner kemudian disebarkan kepada responden untuk diisi. Setelah selesai dalam pengisian kuesioner, kuesioner tersebut dikembalikan kepada penyebar kuesioner. Kuesioner yang telah diisi tersebut akan digunakan oleh peneliti sebagai bahan dalam penelitian ini. 


\section{KESIMPULAN}

\section{Evaluasi Outer Model}

\section{Uji Validity}

Tabel 1. Convergent Validity

\begin{tabular}{|c|c|c|c|c|c|c|}
\hline & $\begin{array}{l}\text { Original } \\
\text { Sample (0) }\end{array}$ & $\begin{array}{c}\text { Sample } \\
\text { Mean (M) }\end{array}$ & $\begin{array}{l}\text { Standard } \\
\text { Deviation } \\
\text { (STDEV) }\end{array}$ & $\begin{array}{l}\text { T Statistics } \\
(\mid \text { O/STDEV } \mid)\end{array}$ & $\begin{array}{c}\mathbf{P} \\
\text { Values }\end{array}$ & \\
\hline \multicolumn{7}{|l|}{$\begin{array}{c}\text { Kompensasi } \\
\text { Finansial (X1) }\end{array}$} \\
\hline $\mathrm{X} 1.1<-\mathrm{X} 1$ & 0,921 & 0,920 & 0,024 & 38,106 & 0,000 & Valid \\
\hline$X 1.2<-X 1$ & 0,887 & 0,883 & 0,042 & 21,238 & 0,000 & Valid \\
\hline$X 1.3<-X 1$ & 0,872 & 0,875 & 0,058 & 15,156 & 0,000 & Valid \\
\hline \multicolumn{7}{|l|}{$\begin{array}{c}\text { Kompensasi } \\
\text { Nonfinansial } \\
\text { (X2) }\end{array}$} \\
\hline$X 2.1<-\mathrm{X} 2$ & 0,765 & 0,718 & 0,158 & 4,857 & 0,000 & Valid \\
\hline$X 2.2<-X 2$ & 0,782 & 0,748 & 0,145 & 5,405 & 0,000 & Valid \\
\hline$X 2.3<-X 2$ & 0,680 & 0,642 & 0,166 & 4,109 & 0,000 & $\begin{array}{l}\text { Valid } \\
\end{array}$ \\
\hline$X 2.4<-$ X2 & 0,843 & 0,835 & 0,109 & 7,767 & 0,000 & Valid \\
\hline \multicolumn{7}{|l|}{$\begin{array}{l}\text { Kepuasan } \\
\text { Kerja (Y1) }\end{array}$} \\
\hline$Y 1.1<-Y 1$ & 0,828 & 0,835 & 0,057 & 14,607 & 0,000 & Valid \\
\hline$Y 1.2<-Y 1$ & 0,837 & 0,841 & 0,065 & 12,950 & 0,000 & Valid \\
\hline$Y 1.3<-Y 1$ & 0,860 & 0,858 & 0,055 & 15,632 & 0,000 & $\begin{array}{l}\text { Valid } \\
\end{array}$ \\
\hline $\mathrm{Y} 1.4<-\mathrm{Y} 1$ & 0,773 & 0,766 & 0,104 & 7,458 & 0,000 & Valid \\
\hline \multicolumn{7}{|l|}{$\begin{array}{c}\text { Kinerja } \\
\text { Karyawan (Y2) }\end{array}$} \\
\hline Y2.1 <- Y2 & 0,891 & 0,893 & 0,050 & 17,807 & 0,000 & Valid \\
\hline$Y 2.2<-Y 2$ & 0,926 & 0,928 & 0,024 & 38,394 & 0,000 & Valid \\
\hline$Y 2.3<-Y 2$ & 0,683 & 0,673 & 0,129 & 5,284 & 0,000 & Valid \\
\hline
\end{tabular}

Convergent validity menjelaskan mengenai kemampuan setiap indikator dalam menjelaskan variabel penelitian yang diteliti. Terdapat tiga pengukuran untuk result for outer loadings yaitu original sample estimate yang menjelaskan tinggi rendahnya kemampuan indikator tersebut dalam menjelaskan variabel yang diteliti, semakin tinggi nilai original sample estimate semakin tinggi pula kemampuan untuk menjelaskan variabel yang diukur. Mean of subsamples menjelaskan tingkat keseragaman jawaban responden. Semakin kecil standar deviasi berarti semakin seragam jawaban responden.

\section{Uji Realibilitas}

Tabel 2. Uji Reabilitas

\begin{tabular}{|c|c|c|c|c|c|c|}
\hline \multicolumn{6}{|c|}{ Item-Total Statistics } & \\
\hline & $\begin{array}{l}\text { Scale } \\
\text { Mean if } \\
\text { Item } \\
\text { Deleted }\end{array}$ & $\begin{array}{l}\text { Scale Variance } \\
\text { if Item Deleted }\end{array}$ & $\begin{array}{l}\text { Corrected } \\
\text { Item-Total } \\
\text { Correlation }\end{array}$ & $\begin{array}{l}\text { Squared } \\
\text { Multiple } \\
\text { Correlation }\end{array}$ & $\begin{array}{l}\text { Cronbach' } \\
\text { s Alpha if } \\
\text { Item } \\
\text { Deleted }\end{array}$ & \\
\hline $\mathrm{X} 1.1$ & 46,94 & 19,323 & ,602 & & ,728 & Reliabel \\
\hline $\mathrm{X} 1.2$ & 46,94 & 19,649 &, 540 & & ,734 & Reliabel \\
\hline
\end{tabular}




\begin{tabular}{|c|c|c|c|c|c|c|}
\hline X1.3 & 46,80 & 19,020 &, 751 &. &, 717 & Reliabel \\
\hline X2.1 & 46,54 & 21,723 &, 080 &. &, 784 & Reliabel \\
\hline X2.2 & 46,58 & 22,534 &,- 034 &. &, 802 & Reliabel \\
\hline X2.3 & 46,20 & 22,490 &, 014 &. &, 784 & Reliabel \\
\hline X2.4 & 46,78 & 24,053 &,- 197 &. &, 812 & Reliabel \\
\hline Y1.1 & 46,94 & 19,323 &, 602 &. &, 728 & Reliabel \\
\hline Y1.2 & 46,94 & 18,956 &, 674 &. &, 721 & Reliabel \\
\hline Y1.3 & 46,78 & 19,767 &, 643 &. &, 729 & Reliabel \\
\hline Y1.4 & 46,68 & 19,447 &, 603 &. &, 728 & Reliabel \\
\hline Y2.1 & 46,94 & 18,956 &, 674 &. &, 721 & Reliabel \\
\hline Y2.2 & 46,90 & 18,990 &, 662 &. &, 722 & Reliabel \\
\hline Y2.3 & 46,72 & 20,124 &, 533 &. &, 737 & Reliabel \\
\hline
\end{tabular}

Dari hasil olahan dengan SPSS semua item Cronbach's Alpha $>0,6$ dan dapat dikatakan reliabel

\section{Evaluasi Inner Model}

\section{Uji Inner Model atau Uji Model Structural}

Uji inner ini digunakan untuk mengevaluasi hubungan antar konstruk laten seperti yang telah dihipotesiskan dalam penelitian, berdasarkan output PLS, didapatkan gambar sebagai berikut:

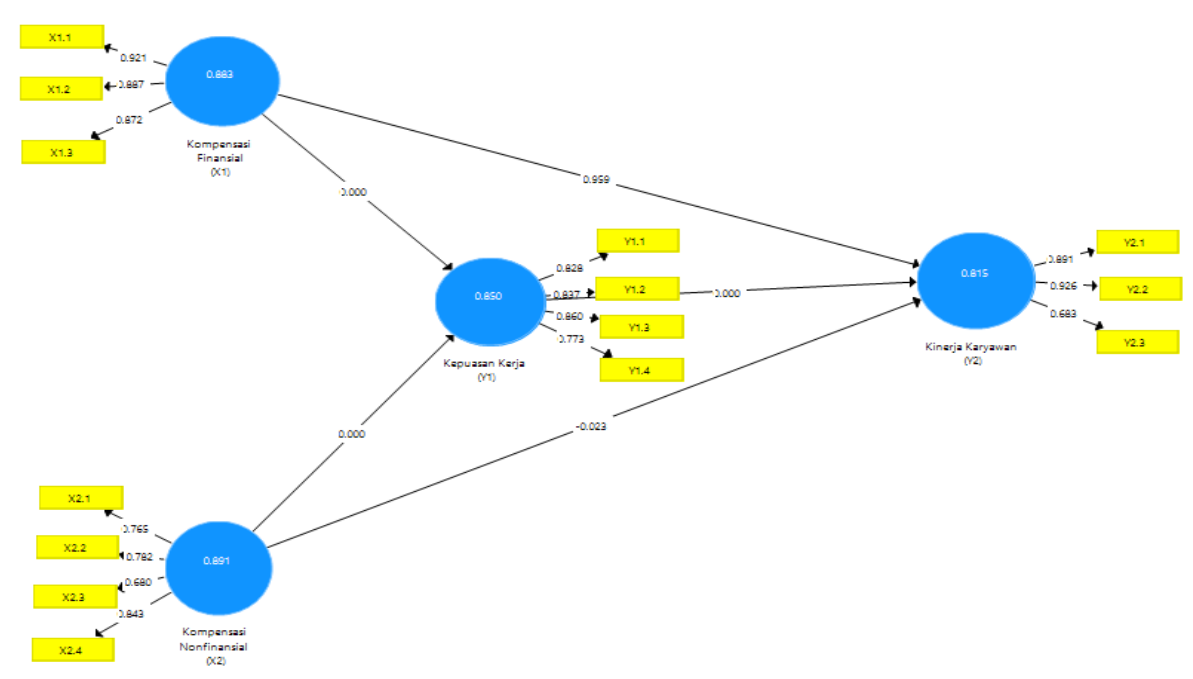

Gambar 1. Model Struktural

\section{Analisis Regresi Linier Berganda}

Mengingat penelitian ini adalah penelitian kualitatif yang dikuantitatifkan dengan menggunakan skala Likert, maka koefisien regresi yang dianalisis adalah Standardized Coeficient, dengan formulasi sebagai berikut:

$$
\begin{aligned}
& Y_{1}=\alpha_{1} x_{1}+\propto_{2} x_{2}+e_{13} \\
& Y_{2}=\beta_{1} x_{1}+\beta_{2} x_{2}+\beta_{3} y_{1}+e_{14}
\end{aligned}
$$

Seteah dilakukan analisis menggunakan SmartPls diperoleh hasil sebagai berikut: 
$Y_{1}=0,913 X_{1}-0,022 X_{2}+e_{13}$

$Y_{2}=-0,110 X_{1}-0,017 X_{2}+1,050 Y_{1}+e_{14}$

$\propto=0,913$ artinya Kompensasi Finansial berpengaruh positif terhadap kepuasan kerja hal ini apabila Kompensasi finansial ditingkatkan sebesar 1 persen makan akan meningkatkan kepuasan kerja sebesar 0,913 persen

$\propto_{2}=-0,022$ artinya Kompensasi Nonfinansial berpengaruh negatif terhadap kepuasan kerja, dalam hal ini apabila Kompensasi nonfinansial ditingkatkan sebesar 1 persen maka akan menurunkan kinerja karyawan sebesar $-0,022$ persen

$Y_{2}=-0,110 X_{1}-0,017 X_{2}+1,050 Y_{1}+e_{14}$

$\beta_{1}=-0,110$ artinya Kompensasi Finansial berpengaruh negatif terhadap Kinerja Karyawan, dalam hal ini apabila Kompensasi Finansial ditingkatkan sebesr 1 persen makan akan menurunkan kinerja karyawan sebesar $-0,110$ persen.

$\beta_{2}=-0,017$ artinya Kompensasi Nonfinansial berpengaruh negatif terhadap Kinerja Karyawan, dalam hal ini apabila kompensasi Nonfinansial ditingkatkan sebesar 1 persen maka akan menurunkan kinerja karyawan sebesar $-0,017$ persen

$\beta_{3}=1,050$ artinya Kepuasan Kerja berpengaruh positif terhadap Kinerja Karyawan, dalam hal ini apabila Kepuasan kerja ditingkatkan sebesar 1 persen maka akan meningkatkan Kinerja Karyawan sebesar 1,050 persen.

\section{Pengujian Hipotesis}

Untuk menjawab Hipotesis penelitian dapat dilihat $\mathrm{t}$-statistic pada tabel 2. berikut:

Tabel 2. Pengujian Hipotesis

\begin{tabular}{|c|c|c|c|c|c|c|}
\hline & $\begin{array}{c}\text { Original } \\
\text { Sample } \\
(0)\end{array}$ & $\begin{array}{c}\text { Sample } \\
\text { Mean } \\
\text { (M) }\end{array}$ & $\begin{array}{c}\text { Standard } \\
\text { Deviation } \\
\text { (STDEV) }\end{array}$ & $\begin{array}{l}\text { T Statistics } \\
\text { (|O/STDEV|) }\end{array}$ & $\begin{array}{c}\mathbf{P} \\
\text { Values }\end{array}$ & keputusan \\
\hline $\begin{array}{c}\text { Finansial (X1) ->> } \\
\text { Kepuasan Kerja (Y1) }\end{array}$ & 0,913 & 0,914 & 0,030 & 30,598 & 0,000 & Diterima \\
\hline $\begin{array}{c}\text { Finansial (X1) -> Kinerja } \\
\text { Karyawan (Y2) }\end{array}$ & $-0,110$ & $-0,123$ & 0,159 & 0,691 & 0,490 & Ditolak \\
\hline $\begin{array}{l}\text { Nonfinansial (X2) -> } \\
\text { Kepuasan Kerja (Y1) }\end{array}$ & $-0,022$ & $-0,034$ & 0,063 & 0,342 & 0,733 & Ditolak \\
\hline $\begin{array}{c}\text { Nonfinansial (X2) -> } \\
\text { Kinerja Karyawan (Y2) }\end{array}$ & $-0,017$ & $-0,016$ & 0,044 & 0,380 & 0,704 & Ditolak \\
\hline $\begin{array}{l}\text { Kepuasan Kerja (Y1) -> } \\
\text { Kinerja Karyawan (Y2) }\end{array}$ & 1,050 & 1,066 & 0,136 & 7,712 & 0,000 & Diterima \\
\hline
\end{tabular}

Berdasarkan tabel di atas dapat dijelaskan sebagai berikut:

Untuk memperoleh $t_{\text {tabel }}$ dengan level of confidence $95 \%$ atau $\propto=0,05$ dan degree of freedom ( $\mathrm{n}$ $-\mathrm{k}=50-5=45$ ) dengan ketentuan apabila $\mathrm{t}_{\text {hitung }}>\mathrm{t}_{\mathrm{tabel}}, \mathrm{H}_{0}$ ditolak dan Ha diterima sebaliknya apabila $\mathrm{t}_{\text {hitung }}<\mathrm{t}_{\text {tabel }}$, maka $\mathrm{H}_{0}$ diterima dan Ha ditolak.

$\mathrm{X} 1 \mathrm{ke} \mathrm{Y} 1 \rightarrow$ Pengaruh $\mathrm{X} 1 \mathrm{ke} \mathrm{Y} 1$, diperoleh dari $\mathrm{t}_{\text {tabel }}(\propto=0,05, \mathrm{df}(45))=\mathrm{t}_{\text {tabel }}=1.671, \mathrm{t}_{\text {hitung }}=$ $30,598, \mathrm{t}_{\text {hitung }}>\mathrm{t}_{\text {tabel }}$, maka $\mathrm{H}_{0}$ ditolak dan Ha diterima.

\section{Pengujian Hipotesis 1}

$\mathrm{H}_{0}: \propto_{1}=0 \rightarrow$ Tidak terdapat pengaruh signifikan Kompensasi Finansial (X1) terhadap Kepuasan Kerja (Y1)

Ha : $\propto_{1} \neq 0 \rightarrow$ Terdapat pengaruh signifikan Kompensasi Finansial (X1) terhadap Kepuasan Kerja (Y1)

Setelah dibandingkan antara $t_{\text {tabel }}$ dengan $t_{\text {hitung }}$, maka diperoleh $t_{\text {tabel }}=1,671$ dan $t_{\text {hitung }}=30,598$ $\mathrm{t}_{\text {hitung }}>\mathrm{t}_{\mathrm{tabel}}$, yang berarti Ha diterima, $\mathrm{H}_{0}$ ditolak atau dapat disimpulkan bahwa Kompensasi Finansial berpengaruh signifikan terhadap Kepuasan Kerja. 


\section{Pengujian Hipotesis 2}

$\mathrm{H}_{0}: \propto_{2}=0 \rightarrow$ Tidak terdapat pengaruh signifikan Kompensasi Nonfinansial (X2) terhadap Kepuasan Kerja (Y1)

Ha : $\propto_{2} \neq 0 \rightarrow$ Terdapat pengaruh signifikan Kompensasi Nonfinansial (X2) terhadap Kepuasan Kerja (Y1)

Setelah dibandingkan antara $t_{\text {tabel }}$ dengan $t_{\text {hitung }}$, maka di peroleh $t_{\text {tabel }}=1,671, t_{\text {hitung }}=0,691$ atau $\mathrm{t}_{\text {hitung }}<\mathrm{t}_{\text {tabel }}$, maka $\mathrm{H}_{0}$ diterima dan $\mathrm{Ha}$ ditolak atau dapat disimpulkan bahwa Kompensasi Nonfinansial tidak berpengaruh signifikan terhadap Kepuasan Kerja.

\section{Pengujian Hipotesis 3}

$\mathrm{H}_{0}: \beta_{1}=0 \rightarrow$ Tidak terdapat pengaruh signifikan Kompensasi Finansial (X1) terhadap Kinerja Karyawan (Y2)

Ha $: \beta_{1} \neq 0 \rightarrow$ Terdapat pengaruh signifikan Kompensasi Finansial (X1) terhadap Kinerja Karyawan (Y2)

Setelah dibandingkan antara $\mathrm{t}_{\text {tabel }}$ dengan $\mathrm{t}_{\text {hitung }}$, maka di peroleh $\mathrm{t}_{\text {tabel }}=1,671, \mathrm{t}_{\text {hitung }}=0,342$ atau $\mathrm{t}_{\text {hitung }}<\mathrm{t}_{\text {tabel }}$, maka $\mathrm{H}_{0}$ diterima dan $\mathrm{Ha}$ ditolak atau dapat disimpulkan bahwa Kompensasi Finansial tidak berpengaruh signifikan terhadap Kinerja Karyawan

\section{Pengujian Hipotesis 4}

$\mathrm{H}_{0}: \beta_{2}=0 \rightarrow$ Tidak terdapat pengaruh signifikan Kompensasi Nonfinansial (X1) terhadap Kinerja Karyawan (Y2)

Ha : $\beta_{2} \neq 0 \rightarrow$ Terdapat pengaruh signifikan Kompensasi Nonfinansial (X1) terhadap Kinerja Karyawan (Y2)

Setelah dibandingkan antara $t_{\text {tabel }}$ dengan $t_{\text {hitung }}$, maka di peroleh $t_{\text {tabel }}=1,671, t_{\text {hitung }}=0,380$ atau $\mathrm{t}_{\text {hitung }}<\mathrm{t}_{\text {tabel }}$, maka $\mathrm{H}_{0}$ diterima dan Ha ditolak atau dapat disimpulkan bahwa Kompensasi Nonfinansial tidak berpengaruh signifikan terhadap Kinerja Karyawan

\section{Pengujian Hipotesis 5}

$\mathrm{H}_{0}: \beta_{3}=0 \rightarrow$ Tidak terdapat pengaruh signifikan Kepuasan Kerja (Y1) terhadap Kinerja Karyawan (Y2)

Ha : $\beta_{3} \neq 0 \rightarrow$ Terdapat pengaruh signifikan Kepuasan Kerja (X1) terhadap Kinerja Karyawan (Y2)

Setelah dibandingkan antara $t_{\text {tabel }}$ dengan $t_{\text {hitung }}$, maka diperoleh $t_{\text {tabel }}=1,671$ dan $t_{\text {hitung }}=7,712 t_{\text {hitung }}$

$>\mathrm{t}_{\text {tabel}}$, yang berarti Ha diterima, $\mathrm{H}_{0}$ ditolak atau dapat disimpulkan Kepuasan Kerja berpengaruh signifikan terhadap Kinerja Karyawan.

\section{Pengaruh Kompensasi Finansial Terhadap Kepuasan Kerja}

Berdasarkan hasil penelitian diketahui bahwa Kompensasi Finansial mempunyai pengaruh positif terhadap Kepuasan kerja, ini berarti semakin baik Kompensasi yang mencakup gaji, bonus dan tunjangan, maka akan meningkatkan kepuasan kerja karyawan. Hal ini beralasan, bahwa setiap karyawan menginginkan kompensasi yang baik dan sesuai yang diharapkan mereka, baik itu kompensasi finansial maupun nonfinansial. Dengan meningkatnya kompensasi finansial maka karyawan akan merasa lebih puas dan lebih giat dalam bekerja. Berdasarkan data yang diperoleh, dapat dijelaskan bahwa karyawan di perusahaan merasa puas memberi penilaian yang tinggi terhadap perusahaan, terutama dalam hal kompensasi dan terbukti signifikan, sehingga hipotesis pertama berbunyi "Diduga Kompensasi Finansial Mempengaruhi Kepuasan Kerja pada PT. Cindara Pratama Lines" dinyatakan diterima. Dalam variabel kompensasi finansial terdapat tiga indikator, yaitu gaji, bonus, dan tunjangan. Yang tertinggi diantara ketiga indikator tersebut yaitu gaji. Dalam hal ini pemberian gaji sudah sesuai dengan tuntutan pekerjaan mereka. Namun jika perusahaan lebih meningkatkan gaji maka kepuasan kerja karyawan akan semakin meningkat.

Dalam variabel kepuasan kerja terdapat empat indikator yaitu gaji yang diterima, kesempatan atau promosi, rekan kerja dan lingkungan kerja. Keempat indikator tersebut memiliki nilai rata-rata yang tinggi. Indikator rekan kerja memiliki nilai mean terendah diantara indikator 
lain. Hasil penelitian ini mendukung penelitian yang dilakukan oleh Diana Lintang Purnamasari dan Hamidah Nayati Utami (2018) bahwa Kompensasi Finansial berpengaruh signifikan terhadap Kepuasan Kerja Karyawan, meskipun masih ada faktor lain yang mempengaruhinya namun Kompensasi Finansial berpengaruh signifikan. Hal ini dibuktikan dengan nilai koefisien jalur sebesar 2,694 dan signifikan dengan probabilitas sebesar 0,000 ( $<<0,05)$. Kemudian dibuktikan dengan nilai skor rata-rata variabel Kompensasi Finansial sebesar 3,71.

\section{Pengaruh Kompensasi Finansial terhadap Kinerja Karyawan}

Berdasarkan hasil penelitian diketahui bahwa Kompensasi Finansial mempunyai pengaruh negatif dan tidak signifikan terhadap kinerja karyawan. Hal ini dikarenakan selama ini kenaikan gaji, bonus maupun tunjangan dianggap karyawan masih terlalu rendah dan tidak sesuai dengan yang diharapkan, sehingga karyawan cenderung dan tidak memberi semangat untuk bekerja bahkan cenderung mengecewakan karyawan yang agak berdampak negatif pada kiinerja mereka dengan harapan perusahaan lebih meningkatkan gaji, bonus maupun tunjangan mereka, namun tidak terlalu tampak dan terbukti dengan hasil terbukti tidak signifikan sehingga hipotesis kedua yang berbunyi "Diduga Kompensasi Finansial mempengaruhi Kinerja Karyawan pada PT. Cindara Pratama Lines Balikpapan" dinyatakan ditolak.

Hal tersebut berbanding terbalik dengan teori yang menyatakan jika Kompensasi Finansial meningkat maka Kinerja Karyawan pun akan meningkat. Pendapat tersebut juga dikemukakan oleh tokoh yang menyatakan bahwa Kompensasi Finansial dapat mempengaruhi pekerjaan itu sendiri. Sebab kompensasi yang baik maka akan menghasilkan suatu hasil yang baik pula. Dalam Kompensasi Finansial terdapat tiga indikator, yaitu gaji, bonus, dan tunjangan. Dalam Indikator tersebut yang tertinggi diantara ketiga indikator tersebut yaitu gaji, pemberian gaji sudah sesuai dengan tuntutan pekerjaan mereka. Dalam variabel Kinerja Karyawan terdapat tiga indikator, yaitu target yang ditetapkan tercapai, pelaksanaan pekerjaan tepat waktu, dan menghasilkan kerja yang berkualitas. Dari ketiga indikator tersebut nilai rata-rata yang tertinggi adalah pelaksanaan pekerjaan tepat waktu. Namun hubungan antara variabel tersebut tidak lah signifikan, hal ini beralasan dengan adanya penilaian dari atasan kepada karyawan, dikarenakan atasan menilai bahwa kinerja karyawan itu sendiri tidak terlaksana sesuai dengan waktu yang ditargetkan. Hal ini juga mengidentifikasi bahwa sebagian besar karyawan pada perusahaan belum menunjukkan prestasi sehingga kenaikan gaji bukan menjadikan hal positip atau meningkatkan kinerja tapi malah menurunkan kinerja, kendati tidak signifikan. Maka dari itu perusahaan harus lebih memperhatikan kinerja dari setiap karyawan agar menjadi dorongan dalam bekerja lebih giat dan tepat waktu. Hal ini mengkonfirmasi teori kompensasi yang dikemukakan oleh Samsudin (2010:188) yang berpendapat bahwa salah satu dari fungsi kompensasi bagi karyawan berprestasi akan mendorong mereka untuk bekerja lebih baik. Namun hasil ini berbeda dengan hasil penelitian yang dilakukan oleh Irham Rif'an Sulhi (2017) yang membuktikan bahwa kompensasi finansial berpengaruh signifikan terhadap kinerja karyawan.

\section{Pengaruh Kompensasi Nonfinansial Terhadap Kepuasan Kerja}

Berdasarkan hasil penelitian diketahui bahwa Kompensasi Nonfinansial tidak mempunyai pengaruh terhadap kepuasan Kerja yaitu negatif, sehingga hipotesis kedua yang berbunyi "Diduga Kompensasi Nonfinansial mempengaruhi Kepuasan Kerja pada PT. Cindara Pratama Lines Balikpapan" dinyatakan ditolak, hal tersebut beralasan dikarenakan faktor-faktor dari karakteristik responden karyawan yang merupakan lulusan SMA dan D3 yang tidak memikirkan tentang pujian maupun penghargaan, karyawan tersebut lebih mengutamakan dengan finansial atau gaji, bonus dan tunjangan yang mereka terima, selain itu tingkat kebutuhan karyawan disini masih pada tingkatan kebutuhan rasa aman, (makan, sandang dan pangan) sehingga gaji, bonus, dan tunjanganlah yang diutamakan mereka bagi memenuhi kebutuhan tersebut dan sekaligus akan memberikan rasa kepuasan mereka. Hasil penelitian ini tidak mengkonfirmasi tentang teori kompensasi non finansial yang dikemukakan oleh Mondy dan Martocchio (2016: 247) yang berpendapat bahwa kompensasi adalah untuk meningkatkan kepuasan kerja dan kinerja karyawan. Hal tersebut berbanding terbalik dengan teori yang menyatakan jika Kompensasi 
Nonfinansial meningkat maka Kepuasan Kerja pun akan meningkat. Pendapat tersebut juga dikemukakan oleh tokoh yang menyatakan bahwa Kompensasi Nonfinansial dapat mempengaruhi pekerjaan itu sendiri. Sebab kompensasi yang baik maka akan menghasilkan suatu hasil yang baik pula. Dalam Kompensasi Nonfinansial terdapat dua indikator, yaitu pekerjaan dan lingkungan kerja. Dalam Indikator tersebut yang tertinggi diantara kedua indikator tersebut yaitu Lingkungan Kerja. Dalam variabel Kepuasan Kerja terdapat empat indikator, yaitu gaji yang diterima, kesempatan atau promosi, rekan kerja dan lingkungan kerja. Dari keempat indikator tersebut nilai rata-rata yang tertinggi adalah Rekan Kerja. Namun hubungan antara variabel tersebut tidak lah signifikan, hal ini dikarenakan sesama dengan rekan kerja tidak bisa menciptakan kerja sama yang baik di dalam lingkungan kerja. Menurut Robbins (1996 : 179) adalah suatu sikap umum seorang individu terhadap pekerjaannya. Pekerjaan menuntut interaksi dengan rekan kerja, atasan, peraturan dan kebijakan organisasi, standar kinerja, kondisi kerja dan sebagainya. Seorang dengan tingkat kepuasan kerja tinggi menunjukkan sikap positif terhadap pekerjaan itu, sebaliknya seorang tidak puas dengan pekerjaanya menunjukkan sikap negatif terhadap pekerjaanya itu.

Namun berbanding terbalik dengan penelitian yang dilakukan oleh Diana Lintang Purnamasari dan Hamidah Nayati Utami (2018) bahwa Kompensasi Nonfinansial berpengaruh positif terhadap Kepuasan Kerja. Hal ini dibuktikan dengan nilai koefisien sebesar 0,061 dan signifikan dengan probabilitas sebesar 0,000 $(\mathrm{p}<0,05)$. Kemudian dibuktikan dengan nilai skor rata-rata variabel Kompensasi Nonfinansial sebesar 3,97.

\section{Pengaruh Kompensasi Nonfinansial terhadap Kinerja Karyawan}

Berdasarkan hasil penelitian diketahui bahwa Kompensasi Non Finansial berpengaruh negatif namun tidak signifikan terhadap Kinerja Karyawan, sehingga hipotesis kedua yang berbunyi "Diduga Kompensasi Finansial mempengaruhi Kinerja Karyawan pada PT. Cindara Pratama Lines Balikpapan" dinyatakan ditolak. Hal ini dikarenakan pada dasarnya sebagian besar karyawan tidak terlalu memperhatikan kompensasi non finansial tersebut, baik itu lingkungan kerja, suasana kerja dan lain-lain, dan justru peningkatan kompensasi non finansial yang dilakukan oleh perusahaan justru dianggap sebagai sebuah kewajiban yang kontra produktif dan cenderung menurunkan semangat kerja karyawan, sehingga berdampak negatif terhadap kinerja karyawan itu sendiri. Hal ini tidak mengkonfirmasi teori Mondy dan Martocchio (2016: 247) yang berpendapat bahwa kompensasi adalah untuk meningkatkan kepuasan kerja dan kinerja karyawan.

Namun berbanding terbalik dengan penelitian yang dilakukan oleh Diana Lintang Purnamasari dan Hamidah Nayati Utami (2018) bahwa Kompensasi Nonfinansial berpengaruh positif terhadap Kepuasan Kerja. Hal ini dibuktikan dengan nilai koefisien sebesar 0,061 dan signifikan dengan probabilitas sebesar 0,000 $(\mathrm{p}<0,05)$. Kemudian dibuktikan dengan nilai skor rata-rata variabel Kompensasi Nonfinansial sebesar 3,97.

\section{Pengaruh Kepuasan Kerja terhadap Kinerja Karyawan}

Berdasarkan hasil penelitian diketahui bahwa Kepuasan Kerja mempunyai pengaruh positif signifikan terhadap Kinerja Karyawan, ini berarti semakin meningkatnya kepuasan kerja seseorang maka akan meningkat pula kinerja nya, dikarenakan saat orang mengalami kepuasan akan kompensasi finansial maupun nonfinansial, seperti gaji atau pun penghargaan yang diberikan oleh perusahaan maka karyawan tersebut akan semakin giat dalam bekerja dan akan meningkatkan kinerja. sehingga hipotesis kelima berbunyi "Diduga Kepuasan Kerja Mempengaruhi Kinerja Karyawan pada PT. Cindara Pratama Lines" dinyatakan diterima. Dalam variabel kepuasan kerja terdapat empat indikator, yaitu gaji yang diterima, kesempatan atau promosi, rekan kerja dan lingkungan kerja. Yang tertinggi diantara keempat indikator tersebut yaitu rekan kerja. Dalam variabel Kinerja Karyawan terdapat tiga indiktor yaitu target yang ditetapkan tercapai, pelaksanaan pekerjaan tepat waktu, dan menghasilkan kerja yang berkualitas. Dari ketiga indikator tersebut pelaksanaan pekerjaan tepat waktu memiliki nilai rata-rata yang tinggi. Dari hubungan antar variabel tersebut bisa dilihat dari indikator bahwa saat sesama rekan 
kerja puas bekerja satu sama lain dan saling membantu maka pekerjaan yang dilakukan pun akan selesai tepat pada waktunya dikarenakan para karyawan nyaman saat melakukan teamwork. Ternyata sebagian besar karyawan merasa puas terhadap kompensasi yang diberikan, khususnya kompensasi finansial, dan kepuasan ini ternyata berpengaruh pada semangat dan motivasi kerja, secara langsung berpengaruh positip signifikan terhadap kinerja karyawan. Hasil ini mengkonfirmasi teori kompensasi oleh Mondy dan Martocchio (2016: 247) yang berpendapat bahwa kompensasi adalah untuk meningkatkan kepuasan kerja dan kinerja karyawan. Selain itu hasil penelitian ini juga mendukung penelitian yang dilakukan oleh Oxy Rindiantika Sari dan Heru Susilo (2018) bahwa Kepuasan Kerja berpengaruh signifikan terhadap Kinerja Karyawan, meskipun masih ada faktor lain yang mempengaruhinya namun Kepuasan Kerja berpengaruh signifikan.

Setelah penulis melakukan perhitungan dengan menggunakan alat bantu SmartPls, pada Bab V sebagai bab analisis dan pembahasan tentang Pengaruh Kompensasi Finansial dan Nonfinansial Terhadap Kepuasan Kerja dan Kinerja Karyawan pada PT Cindara Pratama Lines Balikpapan, maka penulis mengambil kesimpulan sebagai berikut:

1. Variabel Kompensasi Finansial (X1) berpengaruh signifikan terhadap Kepuasan Kerja Karyawan (Y1) pada PT Cindara Pratama Lines Balikpapan.

2. Variabel Kompensasi Finansial (X1) tidak berpengaruh signifikan terhadap Kinerja Karyawan (Y2) pada PT Cindara Pratama Lines Balikpapan.

3. Variabel Kompensasi Nonfinansial (X2) tidak berpengaruh signifikan terhadap Kepuasan Kerja Karyawan (Y1) PT Cindara Pratama Lines Balikpapan.

4. Variabel Kompensasi Nonfinansial (X2) tidak berpengaruh signifikan terhadap Kinerja Karyawan (Y2) PT Cindara Pratama Lines Balikpapan.

5. Sebagai variabel intervening Kepuasan Kerja Karyawan (Y1) berpengaruh signifikan terhadap Kinerja Karyawan (Y2) PT Cindara Pratama Lines Balikpapan.

\section{UCAPAN TERIMA KASIH}

Ucapan Terima Kasih kepada Kementerian Teknologi Riset, dan Pendidikan Tinggi Republik Indonesia pada skema Hibah Penelitian Tesis Magister tahun pendanaan 2019 dan Program Studi S2 Magister Teknik Kimia, Jurusan Teknik Kimia, Fakultas Teknik, Universitas Muhammadiyah Jakarta (UMJ) dan LPPM UMJ atas fasilitas dan dukungan terkait pendanaan penelitian ini.

\section{DAFTAR PUSTAKA}

Arikunto. (2006). Prosedur Penelitian Suatu Pendekatan Praktik. Jakarta: PT. Rineka Cipta.

Hariandja, M. T. (2002). Manajemen Sumber Daya Manusia. Jakarta: PT. Grasindo.

Hasibuan, D. H. (2011). Manajemen Sumber Daya Manusia (15 ed.). Jakarta: PT Bumi Aksara.

Kreitner, R., \& Kinicky, A. (2001). Organizational Behaviour. New York: McGrawHill.

Mangkunegara, A. P. (2000). Manajemen Sumber Daya Manusia Perusahaan, Cetakan kedua. Bandung: PT. Remaja Rosdakarya. 